\title{
Effect of Yoga on the Memory of Middle School Level Students
}

\author{
Dr.Shikha Banerjee \\ Assistant Professor, Institute of Teachers Education, Pt.Ravishankar Shukla University Raipur (Chhattishgarh)
}

\begin{abstract}
Yoga, the scientific wealth of India, yoga is one of the greatest gift of India to the world.It has been an important part of daily routine for the Indian lifestyle., Today Yoga has become one of the most popular system of health and healing, all over the world. The sample of The present study comprises 40 students of the seventh class from school of Raipur C.G. The pre and post test of experimental and control group design was followed. There were two groups (control group and experimental group) and 20 students were assigned to each group. The experiment was conducted for 60 days with yoga practice viz. suryanamaskar, pranayam(anulomvilom), bhramari,omkar jap, and yoga nidra regularly in the morning hours..Memory scale from P.G.I. memory scale from N.N.Wig was used. In within group comparison, memory scores $(t=9.90, p<0.05)$ and between boys and girls also were significantly influenced.
\end{abstract}

Key Words: Yoga practice, Memory, Surya namaskar, Pranayama (anulom-vilom) and Yoga nidra

\section{Introduction}

The role of yoga in education from various angles, including the type of education that was being provided to children throughout the world as well as, the different levels of stress, that children have to face in the classroom environment, has been studied and analysed. The difficulties, problems, conflicts, distraction and dissipation of their energies were also considered.Weare educating our children without taking into consideration the, different angles of their personality. We are cramming their brain and minds with information, without creating any support group outside or the environment, where they can continue to imbibe education. Brain is only the medium through which we educate our mind. The mind is a composition of four different faculties, which has been defined as Manas, Buddhi, Chitta and Ahankara in yogic terminology. The word Manas means to rationalize,to think about somethingWord,Buddhi means intellect, Chitta is an area of consciousness where impressions are stored. Ahankara is the concept of Ego. In the modern education system we are feeling only one aspect of the mind-Buddhi. We are not dealing with the Manas aspect, which deals with the faculty to know what is right and what is wrong. Neither we are dealing with Chitta, where impressions of knowledge are stored in the form of memory and experience nor are with Ahankara, the Ego., rather, we are cramming Buddhi with information only without boosting up the other aspects of mind therefore, despite all our education efforts .we are still unable to apply it constructively and creatively in our lives.

Proper education can only be received, when you allow children to use their intuitive, and intellectual abilities, when you allow them to overcome their fears and inhibitions, to overcome the psychological pressure which has been created by us on them by imposing our own conditions.

The system of educating children has to be combined, with certain practices which can remove their psychological blocks, which can make them aware of the psychological changes that has happened in their body and brain, which can make them aware of their own distractions and which can give them the ability to focus more steadily on theme of the subject they are studying.

The Sanskrit term for memory is Smiriti or Smaran. Remembering is the function of the subconscious mind or Chitta. The Sanskar,or habits of thinking and acting, are deeply impressed in the Chitta, which is like the sensitive plate of of a camera., where all impressions are in deliberately recorded . Whenever, you attempt to remember past events or things, they come back to the surface of the mind through the trap door where ,they come out, in the form of big waves of thought or as mental images.

Memory is the capacity to retain and recall information about past and present incidents. Memory capacity, is the ability to analyze and synthesise the assimilated information and not informationstorage alone. Memory power varies between individuals.

While the Memory is latent capacity to retain and recall information, Yoga assists in improving the memory power with yogic techniques of concentration and meditation. The Brain function of attention,cognition,processing of sensory information and visual perception are toned with yogic practices. Yogic practices help to calm the mind and enhance concentration skills by increasing the circulation of blood to the brain through its asanas, pranayamas, meditation and ohm chanting. Memory lapses can also be prevented, through yogic practices that enhance the power of recall. One can draw upon the immense power of the mind with consistent yogic endeavor. 
Memory and proper perception, without doubt, help for better learning. Sometimes, learning is affected due to appearance of Mental fatigue, which is a state of disturbed perception and memory. It is important to note that regular practice of yoga increases both Memory (Kocher,1976a)and Perception (Sahu\&Gharote1985) on one hand and delay Mental fatigue(Kocher,1976b) on the other hand. Thus Yoga indicates its usefulness in improvement or betterment in learning ability (Bera,Kulkarni,Gore,Ghogal\&Oak,2005) and academic achievement (Ganguly,Bera\&Gharote,2002) especially for school children.

\section{Methodology}

The sample for the study were collected from school of Raipur .Those who had been practicing ,constituted the experiment group and those who had not been practicing sample was recruited as control group.Into the group with 20 students in yoga group and 20 students in non practitioner yoga group. The yoga class was conducted every day in the morning between $6 \mathrm{am}$ to $7 \mathrm{am}$. The following practices were performed every day.Surya namaskar,Pranayam,Omkar chanting Yognidra.

\section{Objectives}

1. To study the memory of students of experimental and control groups at pre test and post test.

2. To study the memory of girl of experimental and control group at pre test and post test.

3.To study the memory of boys of experimental and control group at pre and post.

\section{Hypothesis}

Ho1. There will be no significant difference in memory scores of students of experimental and control groups at pre test and post test.

Ho2. There will be no significant difference in memory scores of girls of experimental and control group at pre test and post test.

Ho3.There will be no significant difference in memory scores of boys of experimental and control group at pre and post.

\section{Observation}

The Pre and post scores on memory obtained for both the experimental and control groups were treated statistically to assess the effect of the practice. Table-1 shows the pre and post comparison of memory for the experimental and control groups. In the experimental group the mean pre value of 52.6 increased to 78.6 in the post condition, the mean difference being found to be highly significant $(p<0.05)$.In the control group the pre mean pre mean value of 52.4 reduced to 55.9 in the post condition, the mean difference being statistically significant.

Table no. 1

Mean,S.D.,t-value of experimental and control group of students

\begin{tabular}{|c|c|c|c|c|c|c|c|c|}
\hline s.no. & Group & Condition & No. & Mean & $\begin{array}{l}\text { Standard } \\
\text { deviation }\end{array}$ & $\begin{array}{l}\text { Standard } \\
\text { error }\end{array}$ & $\mathrm{t}$-value & $\begin{array}{l}\text { Significance } \\
\text { level }\end{array}$ \\
\hline \multirow[t]{2}{*}{$1-$} & \multirow[t]{2}{*}{ Experimental } & pre & 20 & 52.6 & 7.02 & \multirow[b]{2}{*}{2.65} & \multirow[b]{2}{*}{9.90} & \multirow[b]{2}{*}{0.05} \\
\hline & & post & 20 & 78.9 & 9.57 & & & \\
\hline \multirow[t]{2}{*}{$2-$} & \multirow[t]{2}{*}{ Control } & Pre & 20 & 52.4 & 5.39 & \multirow[b]{2}{*}{1.72} & \multirow[b]{2}{*}{2.01} & \multirow[b]{2}{*}{ NS } \\
\hline & & Post & 20 & 55.9 & 5.51 & & & \\
\hline
\end{tabular}

Table-2 shows the pre and post comparison of memory for the experimental and control group of girls. In the experimental group of girls the mean pre value of 54.7 increased to 82.4 in the post condition. The mean difference being found to be significant $(p<0.05)$.In the control group of girls the pre mean value of 54 increased to 57.1 in the post condition ,the mean difference being statistically significant.

Table no. 2

Mean, S.D., $t$-value of experimental and control group of girls

\begin{tabular}{|c|c|c|c|c|c|c|c|c|}
\hline s.no. & Group & Condition & $\begin{array}{l}\text { No.of } \\
\text { students }\end{array}$ & Mean & $\begin{array}{l}\text { Standard } \\
\text { deviation }\end{array}$ & $\begin{array}{l}\text { Standard } \\
\text { error }\end{array}$ & t-value & $\begin{array}{l}\text { Significance } \\
\text { level }\end{array}$ \\
\hline \multirow[t]{2}{*}{$1-$} & \multirow{2}{*}{ Experimental } & pre & 10 & 54.7 & 7.60 & \multirow[b]{2}{*}{3.77} & \multirow[b]{2}{*}{7.34} & \multirow[b]{2}{*}{0.05} \\
\hline & & post & 10 & 82.4 & 9.20 & & & \\
\hline \multirow[t]{2}{*}{$2-$} & \multirow[t]{2}{*}{ Control } & Pre & 10 & 54 & 6.51 & \multirow[b]{2}{*}{3.0} & \multirow[b]{2}{*}{1.03} & \multirow[b]{2}{*}{ NS } \\
\hline & & Post & 10 & 57.1 & 6.93 & & & \\
\hline
\end{tabular}


Table- 3 shows the pre and post comparison of memory for the experimental and control group of boys. In the experimental group of boys the mean pre value of 50.5 increased to 75.5 in the post condition. The t-value is 7.28 The mean difference being found to be significant ( $\mathrm{p}<0.05)$.In the control group of boys the pre mean value of 50.8 increased to 53.7 in the post condition, The t-value is 1.85 the mean difference being statistically not significant.

Table no.3

Mean,S.D.,t-value of experimental and control group of boys

\begin{tabular}{|c|c|c|c|c|c|c|c|c|}
\hline s.no. & Group & Condition & $\begin{array}{l}\text { No. of } \\
\text { Students }\end{array}$ & Mean & $\begin{array}{l}\text { Standard } \\
\text { deviation }\end{array}$ & $\begin{array}{l}\text { Standard } \\
\text { error }\end{array}$ & t-value & $\begin{array}{l}\text { Significance } \\
\text { level }\end{array}$ \\
\hline \multirow[t]{2}{*}{$1-$} & \multirow[t]{2}{*}{ Experimental } & pre & 10 & 50.5 & 6.04 & \multirow[b]{2}{*}{3.48} & \multirow[b]{2}{*}{7.28} & \multirow[b]{2}{*}{0.05} \\
\hline & & post & 10 & 75.5 & 9.03 & & & \\
\hline \multirow[t]{2}{*}{$2-$} & \multirow[t]{2}{*}{ Control } & Pre & 10 & 50.8 & 3.64 & \multirow[b]{2}{*}{1.56} & \multirow[b]{2}{*}{1.85} & \multirow[b]{2}{*}{ NS } \\
\hline & & Post & 10 & 53.7 & 3.36 & & & \\
\hline
\end{tabular}

\section{Discussion}

Entrie made in table-1 hypothesis Ho1, viz: "There is no significant difference in memory scores of students of experimental and control group at pre test and post test levels." was rejected in favour of the finding that the experimental group that was exposed to yogic practices reported increases in memory level whereas no such difference was observed in the control group thus H01was rejected.

Entries made in table-2 t-ratio for the mean increased scores of girls between the experimental and control group on memory was found to be significant at 0.05 level of confidence $(t=7.34)$. Thus H02 was rejected as the experimental group students girls.

Entries made in table-3 t-ratio for the mean increased scores of boys between the experimental and control group on memory was found to be significant at 0.05 level of confidence $(t=7.28)$. Thus H03 was rejected as the experimental group (boys) students who were exposed to yogic practices exhibited increases of memory level as compare to their counter part of the control group(boys).

Thus H01,H02,H03 were rejected, as yogic practices did help in increasing memory level among boys and girls of experimental group as compared to the control group boys and girls, who were not exposed to yogic practices.

\section{Result}

There is no significant difference in memory scores of students of experimental and control group at pre test and post test levels was rejected in favour of the finding that yogic practice helped in increasing of memory level from pre test to post test level among students of experimental group as compared to the control group. As the practice in school going students in yogic practice was provided for a period of 2 months that is Surya namaskar, Pranayam,Omkar jap and Yoga nidra, it helped in increasing memory level.

There is no significant difference in the mean increased scores of memory between girls of experimental and control groups was rejected in favour of the finding that yogic practices helped in increases of memory level among girls students of experimental group as compared to the control group. The society has lot of expectation from school going children, whether at home or school. This leads to possibility of development of anxiety,stress among students, as they are not able to perform as per expectation of the parents. Yogic practice helped to increase memory among girls as it has been found in the study.

There is no significant difference in the mean increased score of memory between boys of experimental and control groups was rejected in favour of the finding that yogic practices helped in increasing memory level among boys of experimental group as compare to the control group. The students are facing conflicting situation all the time what to do, what not to do whichleads to decrease in Retention power and Recall. Students face a life, full of stress in the fast, mechanized and competitiveworld of today. Yoga can play an important role in helping students to combat anxiety and stress and control one's mental state. It leads to memory empowerment. Yogic practices were found to be effective in increasing the memory power among students of experimental group as compared to those of the control group who were not exposed to any training in yogic practices.

Yogic practices were found to be effective in increase of memory among girls of experimental group as compared to those of the control group who were not exposed to any training in yogic practices.

Yogic practices were found to be effective in increase of memory among boys of experimental group as compared to those of the control group who were not exposed to any training in yogic practices. 


\section{Suggestion}

The present study has open up fresh areas for further research:

- The present study can be replicated in combination with one or more variables like academic achievement, academic anxiety stress, depression, personality development etc.

- The study could be carried out on teachers to train them and make them mentally and emotionally fit to give healthy scholastic environment to the students, at a very early age ,so as to prevent, the development of school dropouts, disadvantage problem children, etc.

- The period of treatment could be essentially raised, because yoga being an eternal practice requires, substantial time for producing tremendous effect on memory and emotional state, although physical and the therapeutic effects can be seen in comparatively shorter time.

\section{References}

[1]. Arpita(1990)Physiological and psychological effect of Hat Yoga: a Review of literature, The journal of international association of yoga therapist.vol.1,No.1,2

[2]. Arvind,S.(1948) Yogsamanvay, Sri Aurovindo Society,Pondichery,p.74.

[3]. Banerjee,S.(2011)The Study of effect of yoga on Memory, Mental Fatigue and Academic Achievement of $7^{\text {th }}$ class students, Ph.D. Education, PtSunderlal Sharma (open)University, Bilaspur, Chhattishgarh, India.

[4]. Berra,T.K.;Kulkarni ,D.D.;Gore,M.M.;Ghogal, R.S.\& Oak J.P.(2005) effect of yoga on learning correlates in school children,An International Journal,YogaMimansa,Lonavala,India

[5]. Ganguly, S.K.;Bera, T.K.\&Gharote M.L.(2000),Effect of long term yoga training on academic achievement of school going boys, yoga mimansa, lonavala,vol.XXXIV,no.2,p.107-115.

[6]. Kazdinallen E.(2000),Memory, Encyclopedia of psychology,oxford universitypress,vol.5,p.10-13.

[7]. Kocher,H.C.(1976 a),Effects of yogic practice on immediate memory, yoga mimansa, vo.18,No. 3\&4,p.37-62 .

[8]. Kocher,H.C.(1976 b), Influence of yogic practice on mental fatigue(An exploratory), yoga mimansa, vol.18(2),p.1-13.

[9]. Kumar, K.(2004) Yoga nidra and its impact on students wellbeing, Yoga Mimansa,Lonavala, India Vol.XXXVI,no.1\&2,p.71-76

[10]. Mandlik,V.V.\&Barkhede,R.(1999) Effect of Omkar chatting on concentration Memory and Level of Fatigue,retrived fromhttp://www.yogapoint.com

[11]. Santrack,J.W.(2006)Memory, Educational Psychology, University of Texas, Tata MacgraHill,New Delhi,p.248-261.

[12]. Saraswati, N. (2001) The role of yoga in education. Retrived from http://www.yogamag net.

[13]. Saraswati, S. (1994)Yoga Education for children, Yoga Publication Trust, Munger,Bihar,India.p.1-19.

[14]. Saraswati, S. (1997) AsanPranayam Mudra Bandh, Yoga Publication Trust, Munger,Bihar,India.p.1-19.

[15]. Saraswati, V. (2006) BachhoKeSath Yoga AbhyasKaun Kiska Sikhatahai? YogVidya, Sivanand Math, Munger,India.Vol.5.9. p.4347.

[16]. Tallies,S.; Ramaprabhu V. \& Reddy S.(1999) Effect of yoga traning on Maze learning, Vivekanand Yoga Research Foundation, Banglore.

[17]. Verma, V.(2001) Possibilities of Revolutionizing the Education System through Yoga Nidra,Retrieved fromhttp://www.yogamag.net/archive/2004/3may04/revolution.shtml. 